\title{
Modal Damping Ratio of Symmetric Laminate Composite Under the Effect of Attached Mass Using Experimental Design
}

\section{Rahmane Abdelhafid \\ Research Professo Constantine 1 University Faculty of Mechanical Engineering}

Nowadays, the use of composite materials has taken a large place in civilian industries as well as in military and aerospace industries. Therefore, significant investigations about their mechanical and physical properties are needed. The present study addresses the effect of attached mass on damping ratio of symmetric angle ply laminate composite. Furthermore, factor influencing the effect of attached mass on damping ratio of laminate composite are studied using Taguchi method. The considered factors parameters are: attached mass locations from the clamped edge, stacking sequences and boundary conditions. The results of this study indicate that the damping ratio of the laminate composite plates is sensitive to the attached mass, where the damping ratio is found to be proportional to the locations of the attached mass. The findings of this study indicate that the attached mass decreases frequency parameter and increase the damping ratio of the composite plate, if it is inserted at a point other than a nodal line. In addition, the paper presents a good correlation between the numerical results of the fundamental frequency obtained by the ANSYS software and those obtained experimentally.

Keywords : Laminate composite, Fundamental frequency, Damping ratio, Attached mass, vibration.

\section{INTRODUCTION}

The composite materials are fabricated to have better engineering properties than the conventional ones, such as metals. Some of the properties that can be improved by forming composite materials are: stiffness-to-weight ratio, strength, corrosion resistance, thermal properties, fatigue life and wear resistance. With regard to the vibration behaviour of the composite structures, many studies were carried out to control and determine the dynamic characteristics of those materials. So, several authors have performed vibration analysis of laminated composite under various conditions of reinforcement and configuration [1-7].

In many engineering applications such as satellites systems and aviations, substructures are added to the structures. These attached masses have an effect on the response of the main structures, principally, the vibration behaviour [8-10]. Therefore, it is important to understand properties of vibration of the composite plates under diversity of loading conditions with and without attached mass. Several studies have presented vibration analysis of composite materials with concentrated attached masses at separate locations under various arrangements and conditions of reinforcement. The free vibration of a simply supported laminated composite plate with distributed attached mass was presented by Alibeigloo et

Received: December 2020, Accepted: April 2021

Correspondence to: Dr Rahmane Abdelhafid

Faculty of Mechanical Engineering.

Constantine 1 University, Algeria.

Email:rahmanehaf@gmail.com

doi:10.5937/fme2103740A

(C) Faculty of Mechanical Engineering, Belgrade. All rights reserved al. [11]. The problem is solved using Hamilton's Principle. The obtained results showed that the fundamental frequencies depend on the amount of the patch mass and its location. The numerical simulations and experiments of free vibration behaviours of carbon fibre reinforced composite lattice-core sandwich cylinder (LSC) were studied under different boundary conditions, including end-free constraints by Yongshuai Han et al. [12] the results revealed that the attached masses affect the vibration modes and decrease the fundamental frequency. S.M.R. Khalili et al. [13] investigated the free vibrations of a cross-ply composite shell with and without regularly distributed attached mass, under a diversity of conditions such as the thickness of the shell and the thickness of the distributed attached mass using higher order shell theory. The thick laminated circular plates with attached rigid core were investigated on free vibration by Hosseini-Hashemi el al. [14], the results confirm that the present study is in excellent agreement with those of 3-D FEM for thick laminated composites structures. K. Malekzadeh and A. Sayyidmousavi [15] used the finite element method (FEM) under ANSYS, for analysis the free vibration of rectangular sandwich plates with a flexible core, with and without distributed attached mass on the top face sheet. The results show that the attached mass reduces the frequencies of the sandwich plate. A. Rahmane et al. [16] presented a numerical and experimental method for evaluation the effect of attached mass on dynamic properties of composite laminate plates. The study examines the effect of various factors such as number of layers, position of attached mass and fiber orientation) on frequencies. 
With regard to the experiments plan using Taguchi method, different studies were used to investigate the mechanical behaviour of the composite structures. In the study of H. Omidvar et al. [17], the experimental method of Taguchi was used to find the relationship between different factors that control the optimal ballistic behaviour in Kevlar-epoxy composite materials. Tom Sunny et al. [18] used the Taguchi method to study delamination in drilling GFRP composites. The results indicated that feed rate is the more influential factor on delamination than spindle speed. Manjeet Singh et al. [19], studied geometric parameters for double-spindle joint configurations made of nanoclay glass / epoxy laminates by the use of the Taguchi method. The results show that the most significant factor to increase the bearing strength is the $\mathrm{E} / \mathrm{D}$ (the diameter of the first hole) ratio in serial and parallel pin joint configurations. Ch.-Sh. Chen et al. [20] developed an efficient method based on Taguchi method and finite elements to determine the optimum conditions providing the greatest thickness of the shear layer in composites and to quantify the distributions of the fibre orientation in short-fibre-reinforced composites.

Damping is very important to characterize the dynamic behaviour of fibre-reinforced composites regarding to minimization of resonant vibrations. In addition, its measurements are essential for performance control and structural safety. Several authors have studied the effect of damping on laminated composite under different conditions of reinforcement and orientations of layers. Among that studies, the damping behaviour of carbon fibre and flax fibre reinforced polymer (CFRP and FFRP) composites are studied by M. Rueppel et al. [21] the authors used the logarithmic decrement measurements, dynamic analysis and vibration beam measurements, this work demonstrates that the FFRP may efficient at damping compared to CFRP. Wang and Guild [22] used the vibration technique to measure the dynamic modulus of elasticity and damping ratio of wood-based on composites. The results revealed that a good linear agreement exists between dynamic modulus of elasticity and static modulus of elasticity. Aytac Arikoglu and Ahmet Gokay Ozturk [23] presented a novel approach for evaluation of the damping and vibration analysis of arbitrarily curved laminated composite and sandwich beams. The results obtained were indicated that the present study is in very good agreement with the ones that exist in the literature. The paper of $\mathrm{Yi} \mathrm{He}$ et al [24] presents an efficient finite element method (FEM) for computing the modal damping of carbon/epoxy laminated composites using ABAQUS software. The obtained results from this model are in good agreement with the test data. Thus, the proposed by using finite element method is capable of providing an effective method to determine the modal damping of composite materials. D.A. Pereira et al. [25] presented a numerical and experimental method for evaluation of the influence of fibre orientations on the modal characteristics of composite laminates, emphasizing values of modal damping. The results confirm the efficiency of design strategies intended to regulate and augment the damping levels of composite laminates by exploring the different steering of fibre. El Mahi et al.
[26] modelled the damping ratio of the laminate composites. The obtained results showed that the analysis by using Ritz method is able to evaluate fairly well the damping proprieties of unidirectional materials and laminates.

For all of the literature mentioned above the effects of the attached mass on the modal damping ratio of the composite plate were not considered. Therefore, the aim of this work is to fill this gap by studying the effects of the attached mass on the modal damping ratio as a function of three factors (mass locations, boundary conditions: Clamped-Free-Free-Free (CFFF) and Clamped-Free-Clamped-Free (CFCF) and stacking sequences) on damping ratio for fundamental frequency $\left(1^{\mathrm{st}}\right.$ Mode) of laminate composite under flexural vibration. Furthermore, the paper presents a finite element model (FEM) carried out by using ANSYS software and validated experimentally. In the study, factors influencing the effect of attached mass on damping ratio of fundamental frequency are studied using experiments plan by Taguchi method.

\section{EXPERIMENTAL SET-UP}

Experimental tests have been carried out with the aim to understand the dynamic behaviour of laminate composite. The dimensions of the specimens are: $a=270$ $\mathrm{mm}$ (along $\mathrm{x}$ direction), $\mathrm{b}=300 \mathrm{~mm}$ (along y direction). They consist of 8 layers of unidirectional fibre carbon / epoxy (IM7/8552). The thickness of each layer is 0.125 $\mathrm{mm}$.

IM7 carbon fibre is a continuous, high performance, intermediate modulus. The unique properties of IM7 fibre, such as modulus, higher tensile strength and good shear strength, allow structural designers to achieve higher safety margins for the stiffness and strength critical applications. 8552 epoxy matrix is a high performance tough for use in primary aerospace structures. It exhibits good impact resistance and damage tolerance for a wide range of applications. The volume fraction of fibres is calculated and found to be about 0.577 . The mechanical properties for the carbon fibre and the matrix used in the analysis are given in Table 1 [27].

Table1. Mechanical properties of carbon fibre and matrix

\begin{tabular}{|l|l|l|l|l|}
\hline Properties & $\mathrm{E}_{1}(\mathrm{GPa})$ & $\mathrm{E}_{2}(\mathrm{GPa})$ & $\mathrm{G}_{12}(\mathrm{GPa})$ & $v_{12}$ \\
\hline Fibre & 276 & 19.5 & 70 & 0.28 \\
\hline Matrix & 4.76 & 4.76 & 1.74 & 0.37 \\
\hline
\end{tabular}

The mechanical properties of the laminates are given in Table 2.

Table 2. Mechanical properties of IM7/8552 carbon/epoxy [28]

\begin{tabular}{|c|c|c|c|c|c|}
\hline \multicolumn{2}{|c|}{$\begin{array}{c}\text { Young's modulus } \\
(\mathrm{GPa})\end{array}$} & $\begin{array}{c}\text { Shear modulus } \\
(\mathrm{GPa})\end{array}$ & \multicolumn{2}{c|}{ Poisson ratio } \\
\hline $\mathrm{E}_{11}$ & $\mathrm{E}_{22}, \mathrm{E}_{33}$ & $\mathrm{G}_{12}, \mathrm{G}_{13}$ & $\mathrm{G}_{23}$ & $v_{12}, v_{13}$ & $v_{32}$ \\
\hline 164.87 & 9.81 & 4.8 & 3.2 & 0.31 & 0.52 \\
\hline
\end{tabular}

Three laminated composite plates with the symmetrical stacking sequences of $[ \pm 20]_{2 \mathrm{~s}}, \quad[ \pm 25]_{2 \mathrm{~s}}$ and $[ \pm 30]_{2 \mathrm{~s}}$ are excited in free vibration (These staking sequences were chosen on the basis of the great variation in the damping ratios between them, compared to the remaining sequences). The specimens are tested for 
clamped-free-free-free (CFFF) and clamped-free-clamped-free (CFCF) boundary conditions. The experiments are carried out to identify the effect of attached mass on natural frequencies and damping ratio as a function of mass locations from the clamped edge. Figure 1 represents the locations of the attached mass to the plates. The masses are located in the middle of the direction (y) and spaced $67.5 \mathrm{~mm}$ in the $(\mathrm{x})$ direction. The attached mass weight is $\mathrm{M} / 4$, Where $\mathrm{M}$ is about $120 \mathrm{~g}$ and represent the weight of the plates contain 8 layers.

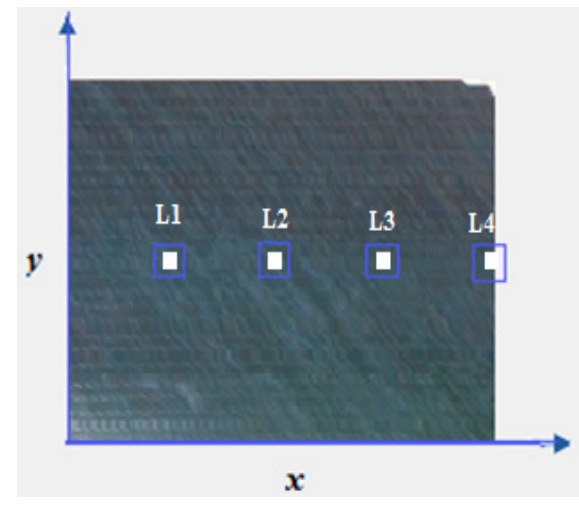

Figure 1. Location of the attached mass

The experimental tests are carried out by using a vibration analyzer of the type B\&K. It is connected to an impact hammer used to induce excitation signal. A low mass accelerometer is used to detect the vibration response. During the measurements, the mass including with the mass of accelerometer was moved on all the mesh measurement points presented in Figure. 1. The experimental equipments are shown in Figure. 2.

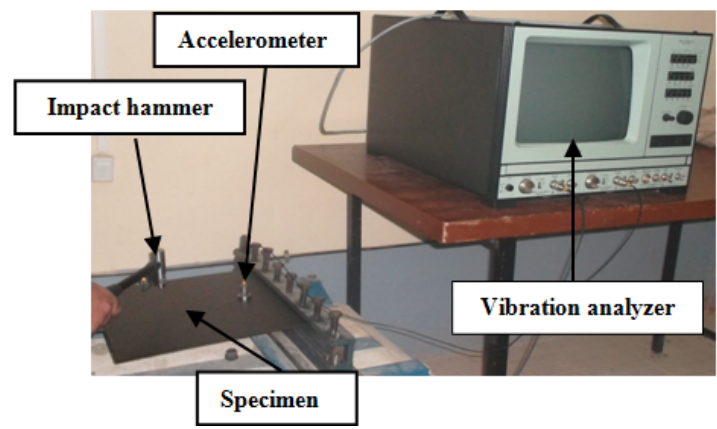

Figure 2. Experimental equipment

The method used for determining the damping at a resonance, is called the Half-Power Bandwidth Method. The approach is based on finding the bandwidth for each mode. The bandwidth is the normalized $\Delta f$ across the resonant response between the $-3 \mathrm{~dB}$ points on the transfer magnitude curve (Figure 4). For a particular mode, the damping ratio $(\zeta)$ can be found from the following equation (1):

$$
\zeta=\frac{\Delta f}{2 f_{r}}
$$

where $\Delta f:$ is the frequency bandwidth between the two half power points. $f r$ : is the resonance frequency.

A model of the response on frequency with attached mass (L3) of the CFFF specimen used in the tests are presented in Figure. 3.

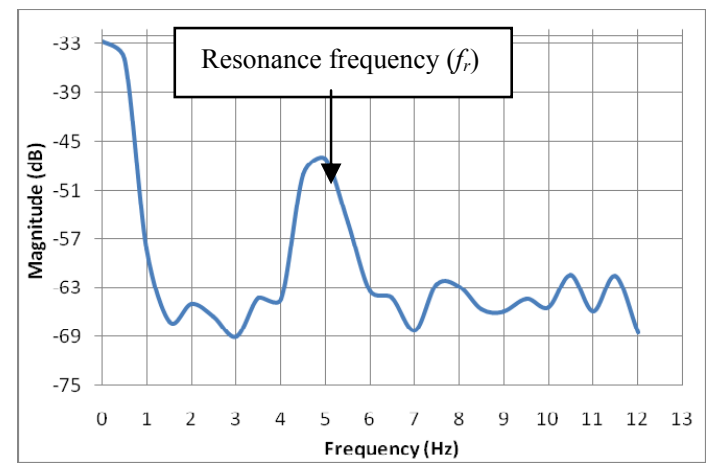

Figure 3. Response of frequency with attached mass of the CFFF specimen $[ \pm 20]_{2 \mathrm{~s}}$

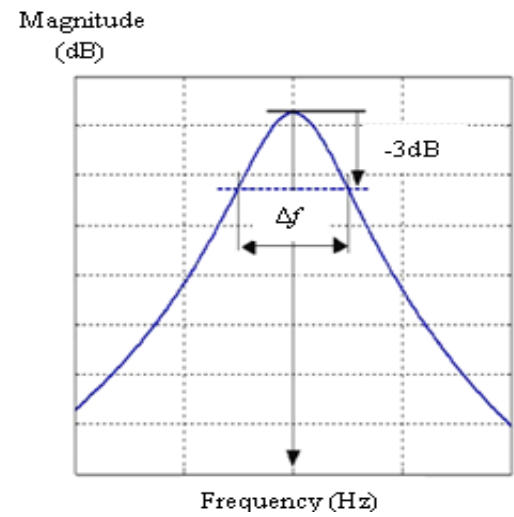

Figure 4. The half-power bandwidth method

\section{ANALYSIS}

The general governing equation of motion of free vibration of the plate system is given by (2):

$$
[M]\{\ddot{y}\}+[K]\{y\}=\{0\}
$$

where $[\mathrm{M}]$ is the structural mass matrix, $[\mathrm{K}]$ is the structural stiffness matrix,

$\{\ddot{y}\}$ is the nodal acceleration vector and $\{\mathrm{y}\}$ is the nodal displacement vector. Equation (2) is used to determine the mode shapes and fundamental frequencies of the plates.

In this work, the plate with and without attached mass is considered for the analysis of modes and fundamental frequencies. The composite plate having thickness $h$ and the $x-y$ plane is the mid-plane of the plate and the z-axis is normal to the plate (Figure. 1). Ordinarily, the resultant forces and moments are written in:

$$
\begin{aligned}
\left\{\begin{array}{l}
N \\
M
\end{array}\right\} & =\left[\begin{array}{ll}
A & B \\
B & D
\end{array}\right]\left\{\begin{array}{l}
\varepsilon^{0} \\
K
\end{array}\right\} \\
A_{i j} & =\sum_{K=1}^{n}\left(Q_{i j}^{\prime}\right)_{K} e_{k} \\
B_{i j} & =\sum_{K=1}^{n}\left(Q_{i j}^{\prime}\right)_{K} e_{k} z_{K} \\
D_{i j} & =\sum_{K=1}^{n}\left(Q_{i j}^{\prime}\right)_{K}\left(e_{k} z_{K}^{2}+\frac{e_{K}^{3}}{12}\right)
\end{aligned}
$$

where the $A_{i j}, B_{i j}$, and $D_{i j}$ are conventional laminate stiffness coefficients and $\mathrm{Q}{ }_{\mathrm{ij}}$ are the components of transformed lamina stiffness matrix. 
The attached mass to the composite plate is assumed to be a point mass. It is assumed that the attached mass does not prevent any bending of the plate. The strain energy of deformation for a thin plate is:

$$
\begin{aligned}
& \begin{array}{r}
\left(\sigma_{x x} \varepsilon_{x x}+\sigma_{y y} \varepsilon_{y y}\right. \\
U_{d}=\frac{1}{2} \iiint+\sigma_{z z} \varepsilon_{z z}+\sigma_{x z} \gamma_{x z}
\end{array} \\
& \left.+\sigma_{y z} \gamma_{y z}+\sigma_{x y} \gamma_{x y}\right) d x d y d z
\end{aligned}
$$

where $\varepsilon_{x}$ and $\varepsilon_{y}$ are the strains along the $x$ and $y$ directions, respectively, and $\gamma_{x y}$ is the shear strain

Taking into account the assumptions of laminate theory: $\sigma_{z z}=\gamma_{x z}=\gamma_{y z}=0$ and in the case of symmetrical laminates, the membrane-bending coupling terms $B_{i j}$ are zero. The strain energy is written:

$$
\begin{gathered}
\left(Q_{11}^{k} \varepsilon_{x x}^{2}+2 Q_{12}^{k} \varepsilon_{x x} \varepsilon_{y y}\right. \\
U_{d}=\frac{1}{2} \iiint_{+2 Q_{16}^{k} \varepsilon_{x x} \gamma_{x y}}^{+2 Q_{y y}^{k} \gamma_{x y}+Q_{22}^{k} \varepsilon_{y y}^{2}} \\
\left.+Q_{66}^{k} \gamma_{x y}^{2}\right) d x d y d z
\end{gathered}
$$

This relation can be expressed according to the displacements $u_{0}, v_{0}$ and $w_{0}$ :

$$
\begin{aligned}
& U_{d}=\frac{1}{2} \iint\left\{A_{11}\left(\frac{\partial u_{0}}{\partial x}\right)^{2}+2 A_{12} \frac{\partial u_{0}}{\partial x} \frac{\partial v_{0}}{\partial y}+A_{22}\left(\frac{\partial v_{0}}{\partial y}\right)^{2}\right. \\
& +2\left(A_{16} \frac{\partial u_{0}}{\partial x}+A_{26} \frac{\partial v_{0}}{\partial y}\right)\left(\frac{\partial u_{0}}{\partial y}+\frac{\partial v_{0}}{\partial x}\right) \\
& +A_{66}\left(\frac{\partial u_{0}}{\partial y}+\frac{\partial v_{0}}{\partial x}\right)^{2}+D_{11}\left(\frac{\partial^{2} w_{0}}{\partial x^{2}}\right)^{2}+2 D_{12} \frac{\partial^{2} w_{0}}{\partial x^{2}} \frac{\partial^{2} w_{0}}{\partial y^{2}} \\
& +D_{22}\left(\frac{\partial^{2} w_{0}}{\partial y^{2}}\right)^{2}+4\left(D_{16} \frac{\partial^{2} w_{0}}{\partial x^{2}}+D_{26} \frac{\partial^{2} w_{0}}{\partial y^{2}}\right) \frac{\partial^{2} w_{0}}{\partial x \partial y} \\
& \left.+4 D_{66}\left(\frac{\partial^{2} w_{0}}{\partial x \partial y}\right)^{2}\right\} d x d y
\end{aligned}
$$

The kinetic energy of a laminate is written:

$$
\begin{aligned}
& E_{c}=\frac{1}{2} \iiint \rho\left[\left(\frac{\partial u}{\partial t}\right)^{2}+\left(\frac{\partial v}{\partial t}\right)^{2}+\left(\frac{\partial w}{\partial t}\right)^{2}\right] d x d y d z \\
& +\frac{1}{2} \sum_{i=1}^{N_{i}} M_{i} w^{2}\left(x_{p}, y_{p}\right)
\end{aligned}
$$

where $\rho$ is the mass per unit area of the plate, $M_{i}$ is the mass of the attached particle,

$\left(x_{p}, y_{p}\right)$ is the position, and $N i$ is the number of particles attached to the composite plate[29].

$$
\begin{gathered}
u=u_{0}-z \frac{\partial w_{0}}{\partial x} ; v=v_{0}-z \frac{\partial w_{0}}{\partial y} ; w=w_{0}(x, y) \\
E_{c}=\frac{1}{2} \iiint\left[\begin{array}{l}
\left(\frac{\partial u_{0}}{\partial t}-z \frac{\partial^{2} w_{0}}{\partial x \partial t}\right)^{2}+\left(\frac{\partial v_{0}}{\partial t}-z \frac{\partial^{2} w_{0}}{\partial y \partial t}\right)^{2} \\
\left.+\left(\frac{\partial w_{0}}{\partial t}\right)^{2}\right] d x d y d z
\end{array}\right] \\
+\frac{1}{2} \sum_{i=1}^{N} M_{i} w^{2}\left(x_{p}, y_{p}\right)
\end{gathered}
$$

The equation of the free transversal vibration is written:

$$
\begin{aligned}
& -\rho_{s} \omega^{2} w_{0}+D_{11} \frac{\partial^{4} w_{0}}{\partial x^{4}}+4 D_{16} \frac{\partial^{4} w_{0}}{\partial x^{3} \partial y} \\
& +2\left(D_{12}+2 D_{66}\right) \frac{\partial^{4} w_{0}}{\partial x^{2} \partial y^{2}}+4 D_{26} \frac{\partial^{4} w_{0}}{\partial x \partial y^{3}}+D_{22} \frac{\partial^{4} w_{0}}{\partial y^{4}}=0
\end{aligned}
$$

The solution of this equation is sought, by the method of separation of the variables of spaces and time, in the form:

$$
w_{0}(x, y, t)=w_{0}(x, y) e^{j \omega t}
$$

$w_{0}(x, y):$ is the spatial or shape solution.

\subsection{Finite Element simulation}

The FEM simulation is realized by using ANSYS software. For the composite laminate material, the element type used is SHELL281.

The element is suitable for analyzing thin to moderately-thick shell structures. The element has eight nodes with six degrees of freedom at each node: translations in the $\mathrm{x}, \mathrm{y}$, and $\mathrm{z}$ axes, and rotations about the $\mathrm{x}, \mathrm{y}$, and $\mathrm{z}$-axes.

The point mass element type which has been used is 3D mass 21 in ANSYS. Figure. 5 shows the finite element model of the attached mass on the composite laminate plates.

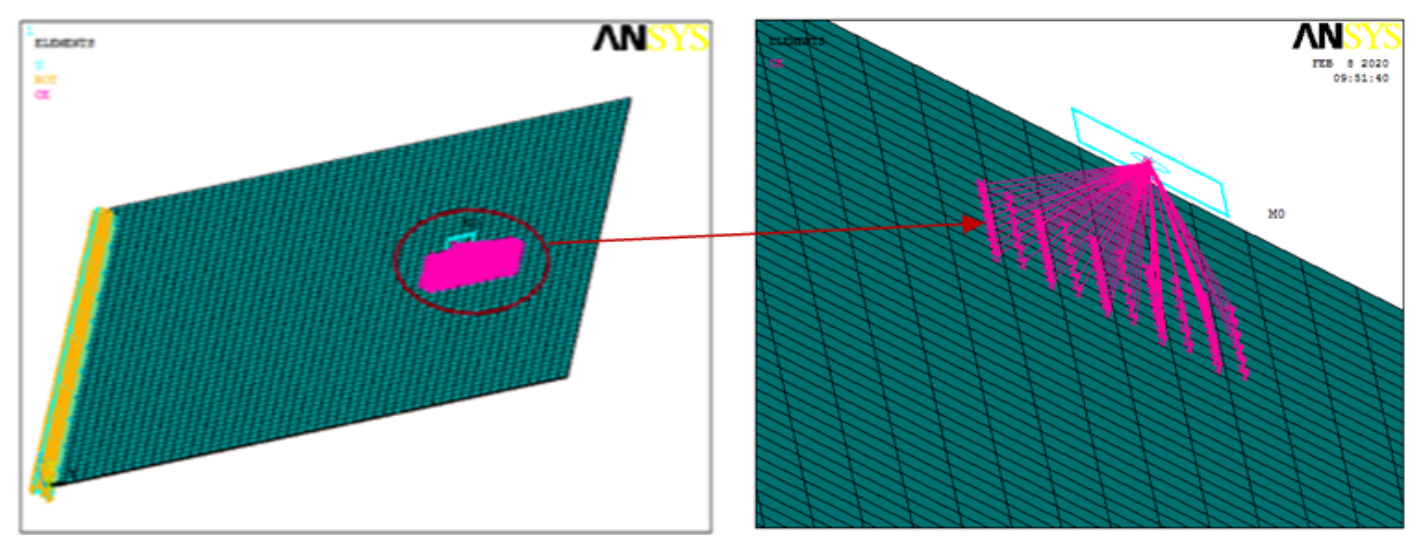

Figure 5. Finite element model of composite laminate plates with mass loading 


\section{THE TAGUCHI METHOD AND DESIGN OF EXPERIMENTS}

The Taguchi methods are statistical methods, developed to improve the quality of manufactured goods, and more recently also applied to biotechnology and engineering. As it can improve the processing quality, and reduce the number of experiments. In addition, the advantage of this method is to save experimental time and locate important factors fast, and save effort during testing.

There are many standard orthogonal arrays available, each of the arrays is meant for a specific number of independent design factors and levels. So, the selection of orthogonal arrays is based on the number of factors and the levels for each experimental application [30]. In this work, we need a large number of experimental tests to achieve the objective of the studies. The Taguchi method uses a small number of tests for research, by the use of a special design of orthogonal arrays. The most suitable mixed orthogonal array L18 $\left(2^{1} \times 3^{2}\right)$ has been used to determine the optimal factors influencing the effect of attached mass on damping ratio for composite laminate plates (Table 3 ). These factors include attached mass locations and the staking sequences for three levels (L1, L2, and L3), $\left([ \pm 20]_{2 \mathrm{~s}},[ \pm 25]_{2 \mathrm{~s}}\right.$ and $\left.[ \pm 30]_{2 \mathrm{~s}}\right)$, and two levels in the case the boundary conditions (CFFF, and CFCF) (Table 4).

The Taguchi method uses a loss function (signalnoise $(\mathrm{S} / \mathrm{N})$ ratio) to calculate the deviation between the desired values and the experimental values.

Better quality characteristic was used as shown in Eq. (15), the large-the-best:

$$
\mu=\frac{S}{N}=-10 \log \left[\frac{1}{n} \sum_{i=1}^{n} \frac{1}{y_{i}^{2}}\right]
$$

where $\mathrm{y}_{\mathrm{i}}$ is the observed data at the $i^{\text {th }}$ experiment and $n$ is the number of observations of the experiment.

Table 3. Taguchi L18 array test design

\begin{tabular}{|c|c|c|c|}
\hline \multirow[t]{2}{*}{ Tests } & \multicolumn{3}{|c|}{ Factors } \\
\hline & A & B & $\mathrm{C}$ \\
\hline 1 & 1 & 1 & 1 \\
\hline 2 & 1 & 1 & 2 \\
\hline 3 & 1 & 1 & 3 \\
\hline 4 & 1 & 2 & 1 \\
\hline 5 & 1 & 2 & 2 \\
\hline 6 & 1 & 2 & 3 \\
\hline 7 & 1 & 3 & 1 \\
\hline 8 & 1 & 3 & 2 \\
\hline 9 & 1 & 3 & 3 \\
\hline 10 & 2 & 1 & 1 \\
\hline 11 & 2 & 1 & 2 \\
\hline 12 & 2 & 1 & 3 \\
\hline 13 & 2 & 2 & 1 \\
\hline 14 & 2 & 2 & 2 \\
\hline 15 & 2 & 2 & 3 \\
\hline 16 & 2 & 3 & 1 \\
\hline 17 & 2 & 3 & 2 \\
\hline 18 & 2 & 3 & 3 \\
\hline
\end{tabular}

The percentage differences between FEM results and the experimental results for $[ \pm 20]_{2 \mathrm{~s}},[ \pm 25]_{2 \mathrm{~s}},[ \pm 30]_{2 \mathrm{~s}}$ laminated composites plates are less than $8.7 \%$.

Table 4. Factors and their levels

\begin{tabular}{|l|c|c|c|c|}
\hline Parameters & Symbol & Level 1 & Level 2 & Level 3 \\
\hline $\begin{array}{l}\text { Boundary } \\
\text { conditions }\end{array}$ & A & CFFF & CFCF & - \\
\hline $\begin{array}{l}\text { Staking } \\
\text { sequences }\end{array}$ & B & {$[ \pm 20]_{2 \mathrm{~s}}$} & {$[ \pm 25]_{2 \mathrm{~s}}$} & {$[ \pm 30]_{2 \mathrm{~s}}$} \\
\hline $\begin{array}{l}\text { Attached mass } \\
\text { locations }\end{array}$ & $\mathrm{C}$ & L1 & L2 & L3 \\
\hline
\end{tabular}

\section{RESULTS AND DISCUSSION}

\subsection{Effect of the attached mass on modal damping and natural frequencies}

In Table 5 the experimental results of the fundamental frequencies of plates composite without attached mass as a function of lamination angle are given. These results are compared with the results of the finite element method (FEM) and good agreement is observed between the two results.

Table 5. Fundamental natural frequencies and modal damping ratio of the CFFF specimens, without attached mass

\begin{tabular}{|l|c|c|c|c|}
\hline \multirow{2}{*}{$\begin{array}{l}\text { Staking } \\
\text { sequences }\end{array}$} & \multicolumn{3}{|c|}{$\begin{array}{c}\text { Fundamental frequency } \mathrm{f}_{\mathrm{r}} \\
(\mathrm{Hz})\end{array}$} & $\begin{array}{c}\text { Modal } \\
\text { damping } \\
(\%)\end{array}$ \\
\cline { 2 - 4 } & Exp & FEM & $\begin{array}{c}\text { Error } \\
(\%)\end{array}$ & \\
\hline$[ \pm 20]_{2 \mathrm{~s}}$ & 6.0 & 5.7913 & 3.3 & 5.480 \\
\hline$[ \pm 25]_{2 \mathrm{~s}}$ & 5.7 & 6.2831 & 8.7 & 4.990 \\
\hline$[ \pm 30]_{2 \mathrm{~s}}$ & 6.6 & 7.0480 & 6.6 & 4.190 \\
\hline
\end{tabular}

Table 6. Fundamental natural frequencies and modal damping ratio with attached mass of the CFFF specimen $[ \pm 20]_{2 s}$

\begin{tabular}{|c|c|c|c|c|}
\hline \multirow{2}{*}{$\begin{array}{l}\text { Locations of } \\
\text { attached } \\
\text { masses }\end{array}$} & \multicolumn{3}{|c|}{ Fundamental frequency $\mathrm{f}_{\mathrm{r}}(\mathrm{Hz})$} & \multirow{2}{*}{$\begin{array}{c}\text { Modal } \\
\text { damping } \\
(\%)\end{array}$} \\
\hline & Exp & FEM & $\begin{array}{c}\text { Error } \\
(\%)\end{array}$ & \\
\hline L1 & 5.6 & 6.084 & 8.5 & 06.01 \\
\hline L2 & 5.2 & 5.683 & 7.6 & 08.1 \\
\hline L3 & 4.8 & 4.993 & 4.04 & 08.5 \\
\hline L4 & 4.4 & 4.393 & 0.16 & 9.09 \\
\hline
\end{tabular}

Table 7. Fundamental natural frequencies and modal damping ratio with attached mass of the CFFF specimen $[ \pm 25]_{2 \mathrm{~s}}$

\begin{tabular}{|c|c|c|c|c|}
\hline \multirow{2}{*}{$\begin{array}{l}\text { Locations of } \\
\text { attached } \\
\text { masses }\end{array}$} & \multicolumn{3}{|c|}{ Fundamental frequency $\mathrm{f}_{\mathrm{r}}(\mathrm{Hz})$} & \multirow{2}{*}{$\begin{array}{c}\text { Modal } \\
\text { damping } \\
(\%)\end{array}$} \\
\hline & Exp & FEM & $\begin{array}{c}\text { Error } \\
(\%)\end{array}$ & \\
\hline L1 & 5.8 & 6.595 & 12.06 & 5.5 \\
\hline L2 & 5.4 & 6.038 & 11.1 & 7.75 \\
\hline L3 & 5.1 & 5.1985 & 1.9 & 8.0 \\
\hline L4 & 4.8 & 4.6506 & 3.1 & 8.33 \\
\hline
\end{tabular}

Table 8. Fundamental natural frequencies and modal damping ratio with attached mass of the CFFF specimen $[ \pm 30]_{2 s}$

\begin{tabular}{|l|c|c|c|c|}
\hline \multirow{2}{*}{$\begin{array}{l}\text { Locations } \\
\text { of attached } \\
\text { masses }\end{array}$} & \multicolumn{2}{|c|}{ Fundamental frequency $\mathrm{f}_{\mathrm{r}}(\mathrm{Hz})$} & \multirow{2}{*}{$\begin{array}{c}\text { Modal } \\
\text { damping } \\
(\%)\end{array}$} \\
\cline { 2 - 4 } & Exp & FEM & $\begin{array}{c}\text { Error } \\
(\%)\end{array}$ & 4.6 \\
\hline L1 & 6.8 & 7.2254 & 5.8 & 7.4 \\
\hline L2 & 6.4 & 6.7913 & 4.7 & 7.6 \\
\hline L4 & 5.9 & 5.8178 & 0.2 & 7.76 \\
\hline
\end{tabular}


L1

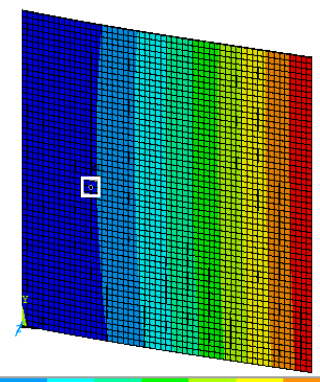

L2

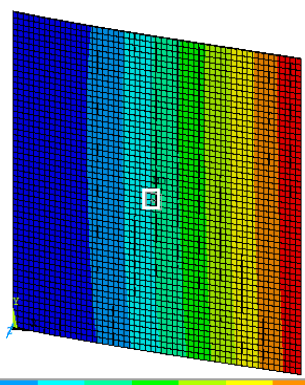

L3

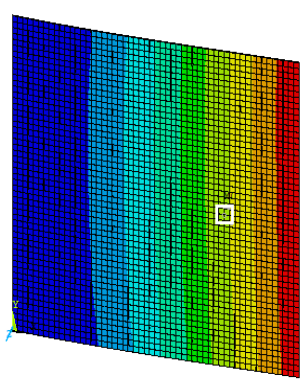

L4

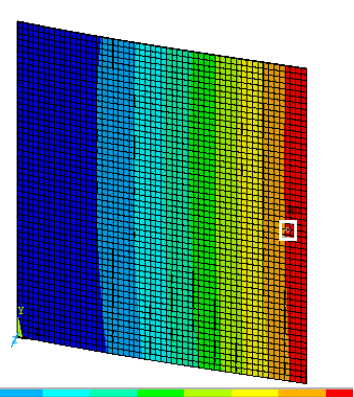

Figure 6. Fundamental numerical mode shapes of $[ \pm 20]_{2 \mathrm{~s}}$ plate with $30 \mathrm{~g}(\mathrm{M} / 4)$ attached mass

The Tables 6-8 the experimental results of the fundamental natural frequencies of plates composite with attached mass (as a function of lamination angle for different locations) are compared with the finite element method (FEM). The percentage differences between FEM results and the experimental results are less than $8.5 \%, 12.06 \%$ and $6.25 \%$ for $[ \pm 20] 2 \mathrm{~s}$, $[ \pm 25] 2 \mathrm{~s},[ \pm 30] 2 \mathrm{~s}$ laminated composites plates respectively. Generally, it is seen that a good agreement exists between numerical and experimental results.

The differences are probably due to the geometric imperfections in the structure of plate's composite, where the difficult to define a perfect clamped edges in experimental tests (due to possible flexibility of the clamping apparatus, neglecting shear deformation), uniform variations in ply thickness and the effect of misalignments in ply orientation, that have not been considered in the numerical model. These errors parameters affect the stiffness, consequently on the frequencies and damping ratio of the plates.

The present result in the Tables 6-8 are compared with that in the Table 5 and shows variation of fundamental frequencies between plates, with and without attached mass. Generally, the fundamental frequency decreases as the location of the attached mass (L1, L2, L3, and $\mathrm{L}_{4}$ ) is closer to the clamped edge (Figure 6).With regard to the damping ratio of fundamental mode of CFFF composite, if the location of the mass is approached to the clamped edge, the change of the damping ratio is not more pronounced. So, the change of damping compared with damping obtained in plate without attached mass is larger when the distance between mass and clamped edge is greater.

All changes in the frequency and damping ratio of the composite plate are related with position of the attached mass with respect to nodal lines in the corresponding mode shapes. If the mass is attached near to a nodal line, attached mass has small amplitudes that lead to small kinetic energy. Therefore, a small change is observed for the frequency and damping ratio of the composite plates.

\subsection{Evaluation and analysis of experimental results using taguchi design}

The values of damping ratio of fundamental frequencies between plates with and without attached mass are very important for the improvement of the quality of dynamic measurements due to the loading of added masses to the composite structures, that they are frequent in the fields of mechanical industry and civil engineering.

Table 9. The results of experiments

\begin{tabular}{|c|c|c|c|c|c|}
\hline \multirow[b]{2}{*}{ Tests } & \multicolumn{3}{|c|}{ Factors } & \multirow{2}{*}{$\begin{array}{c}\text { Damping } \\
\text { ratio } \\
(\%)\end{array}$} & \multirow{2}{*}{$\begin{array}{c}\text { S/N Ratio } \\
\text { for } \\
\text { Damping } \\
\text { ratio }(\%)\end{array}$} \\
\hline & A & B & $\mathrm{C}$ & & \\
\hline 1 & CFFF & {$[ \pm 20]_{2 \mathrm{~s}}$} & L1 & 6.01 & 15.5775 \\
\hline 2 & CFFF & {$[ \pm 20]_{2 \mathrm{~s}}$} & L2 & 8.10 & 18.1697 \\
\hline 3 & CFFF & {$[ \pm 20]_{2 \mathrm{~s}}$} & L3 & 8.50 & 18.5884 \\
\hline 4 & CFFF & {$[ \pm 25]_{2 \mathrm{~s}}$} & $\mathrm{~L} 1$ & 5.50 & 14.8073 \\
\hline 5 & CFFF & {$[ \pm 25]_{2 \mathrm{~s}}$} & $\mathrm{~L} 2$ & 7.75 & 17.7860 \\
\hline 6 & CFFF & {$[ \pm 25]_{2 \mathrm{~s}}$} & L3 & 8.00 & 18.0618 \\
\hline 7 & CFFF & {$[ \pm 30]_{2 \mathrm{~s}}$} & L1 & 4.60 & 13.2552 \\
\hline 8 & CFFF & {$[ \pm 30]_{2 \mathrm{~s}}$} & L2 & 7.40 & 17.3846 \\
\hline 9 & CFFF & {$[ \pm 30]_{2 \mathrm{~s}}$} & L3 & 7.60 & 17.6163 \\
\hline 10 & CFCF & {$[ \pm 20]_{2 \mathrm{~s}}$} & L1 & 1.20 & 1.5836 \\
\hline 11 & CFCF & {$[ \pm 20]_{2 \mathrm{~s}}$} & L2 & 1.6 & 4.0824 \\
\hline 12 & CFCF & {$[ \pm 20]_{2 \mathrm{~s}}$} & L3 & 1.53 & 3.6938 \\
\hline 13 & CFCF & {$[ \pm 25]_{2 \mathrm{~s}}$} & $\mathrm{~L} 1$ & 1.04 & 0.3407 \\
\hline 14 & CFCF & {$[ \pm 25]_{2 \mathrm{~s}}$} & L2 & 1.32 & 2.4115 \\
\hline 15 & CFCF & {$[ \pm 25]_{2 \mathrm{~s}}$} & L3 & 1.21 & 1.6557 \\
\hline 16 & CFCF & {$[ \pm 30]_{2 \mathrm{~s}}$} & L1 & 0.80 & -1.9382 \\
\hline 17 & CFCF & {$[ \pm 30]_{2 \mathrm{~s}}$} & L2 & 0.93 & -0.6303 \\
\hline 18 & CFCF & {$[ \pm 30]_{2 \mathrm{~s}}$} & L3 & 1.1 & 0.8279 \\
\hline
\end{tabular}

The changes in damping ratio were obtained as the result of experimental study are seen in Figures. 7 and 8.

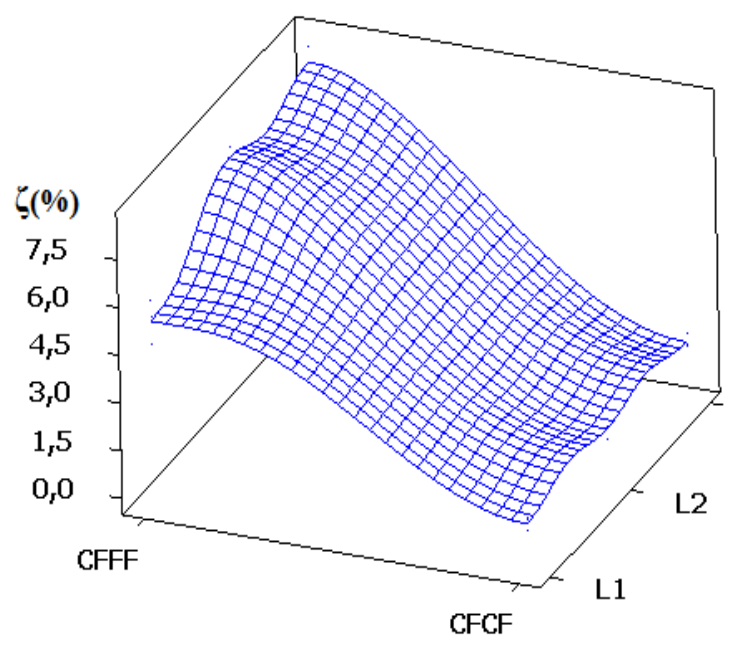

Figure 7. Effect of boundary conditions and attached mass locations on damping ratio 


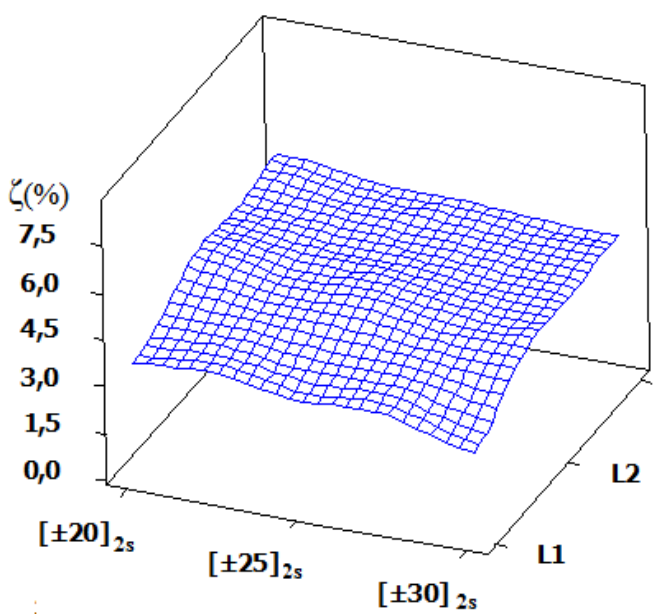

L3

Figure 8. Effect of staking sequences and attached mass locations on damping ratio

Depending on the difference of the attached locations mass (L1, L2 and L3), there was not much change in the damping ratio values for CFCF boundary conditions. However, in CFFF boundary conditions, the values of damping ratio had an important value compared with the values obtained for CFCF boundary conditions (Figure. 7).

The values of damping ratio compared with damping obtained in plate without attached mass is larger when the distance between location of the mass and clamped edge is greater. All changes in the damping ratio of the composite plate are related with position of the attached mass with respect to nodal lines in the corresponding mode shapes (For the first mode the clamped edge is only a nodal line) (Figure 6).

The data is plotted in Figure 8. It indicates that the damping ratio increases with the increase in staking sequences $\left([ \pm 20]_{2 \mathrm{~s}},[ \pm 25]_{2 \mathrm{~s}}\right.$ and $\left.[ \pm 30]_{2 \mathrm{~s}}\right)$ for all attached mass locations (L1, L2 and L3) and for both CFCF and CFFF boundary conditions. This is due to the facts that, the number of lay fiber and staking sequences between lateral and parallel to the bending axis for each modes. Consequently, the bending stiffness of the $[ \pm 20]_{2 \mathrm{~s}}$ becomes lower than that of the $[ \pm 25]_{2 \mathrm{~s}}$ and $[ \pm 30]_{2 \mathrm{~s}}$, and its damping becomes higher.

The "larger-the better" equation was used for the calculation of the $\mathrm{S} / \mathrm{N}$ ratio. Table 9 shows the values of the $\mathrm{S} / \mathrm{N}$ ratios for observations of damping ratio of the fundamental frequencies. In addition, the effect of each control factor was presented with $\mathrm{S} / \mathrm{N}$ response table, and is shown in Table 10. The bold values shows the optimal levels of control factors.
Table 10. S/N response table for the damping ratio of the fundamental mode

\begin{tabular}{|c|c|c|c|}
\hline \multirow{2}{*}{ Levels } & \multicolumn{3}{|c|}{$\begin{array}{c}\text { Control factor } \\
\text { (Damping ratio (\%)) }\end{array}$} \\
\cline { 2 - 4 } & $\begin{array}{c}\text { A (Boundary } \\
\text { conditions) }\end{array}$ & $\begin{array}{c}\mathrm{B} \\
\text { (Staking } \\
\text { sequences) }\end{array}$ & $\begin{array}{c}\mathrm{C} \\
\text { (Attached mass } \\
\text { locations) }\end{array}$ \\
\hline 1 & $\mathbf{1 6 . 8 0 5}$ & $\mathbf{1 0 . 2 8 3}$ & 7.429 \\
\hline 2 & 1.442 & 9.335 & 9.867 \\
\hline 3 & & 7.753 & $\mathbf{1 0 . 0 7 4}$ \\
\hline Delta & 15.363 & 2.530 & 2.645 \\
\hline Rank & 1 & 3 & 2 \\
\hline
\end{tabular}

The level values of control factors are shown in paragraph forms in Figure 9.

The best level was found according to the highest $\mathrm{S} / \mathrm{N}$ ratio in the levels of that control factors. According to this, the levels and $\mathrm{S} / \mathrm{N}$ ratios for the factors giving the best value of damping ratio were specified as $\mathrm{A}$ (Level $1, \mathrm{~S} / \mathrm{N}=16,805$ ), factor $\mathrm{B}$ (Level 1, $\mathrm{S} / \mathrm{N}=10,283$ ), and factor $\mathrm{C}$ (Level 3, $\mathrm{S} / \mathrm{N}=$ $10,074)$. In other words, the optimum value of damping ratio was obtained with a CFFF boundary condition at the point L3 and has a symmetrical stacking sequence $[ \pm 20]_{2 s}$.

\section{CONCLUSION}

This paper presents the findings of an experimental and numerical investigation the dynamic behavior of the composite laminate plates. The focus is made on the effects of attached mass on the damping ratio. In the research, the three factors (attached mass locations, the staking sequences and the boundary conditions) influencing the effect of the attached mass on the damping ratio are studied using the Taguchi method. The paper presents a finite element modeling carried out by using ANSYS software and validated experimentally. Through the results obtained above, the following conclusions could be drawn:

- Attached masses greatly increase damping ratio and reduce the fundamental frequency.

- By changing staking sequences, the attached mass changes the position and shape of nodal lines.

- The attached mass increases the damping ratio of the composite plate if it is inserted at a point other than a nodal line. This change is more pronounced if the mass is attached farther from the nodal lines of the mode shapes.

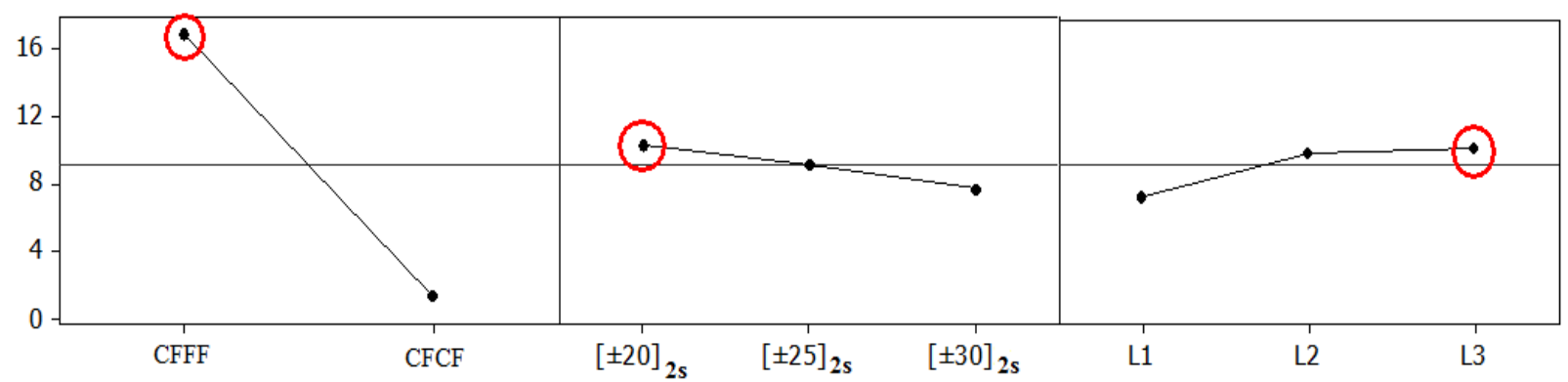

Figure 9. Plot of main effects based on Means and $\mathrm{S} / \mathrm{N}$ ratios for damping ratio 
- The optimum levels of the control factors for indicate the effect of attached mass on damping ratio using $\mathrm{S} / \mathrm{N}$ ratio were determined. The optimal conditions for fundamental vibration mode were observed at A1B1C3.

This result is important from the point of view of the location of the sensor on the plate and the improvement of vibratory measurements by the optimization of emplacement. In addition, can be used to eliminate the mass of accelerometers used in the experimental tests for detection of defaults in the machines by vibration analysis.

\section{REFERENCES}

[1] Fazzolari, F.A., Boscolo, M, Banerjee, J.R.: An exact dynamic stiffness element using a higher order shear deformation theory for free vibration analysis of composite plate assemblies, Compos Struct, Vol. 96, pp. 262-278, 2013.

[2] Jawaid, M., Thariq, M.: Handbook Sustainable Composites for Aerospace Applications, Woodhead Publishing - Elsevier, Cambridge, 2018.

[3] Zweben, C.H. and Beaumont, P.W.R. (Editors): Comprehensive Composite Materials II, 2nd Edition, Elsevier Ltd., Amsterdam, 2018.

[4] Hemmatnezhad, M., Rahimi, GH., Tajik, M., Pellicano, F.: Experimental, numerical and analytical investigation of free vibrational behavior of GFRP-stiffened composite cylindrical shells, Compos Struct. Vol. 120, pp. 509-518, 2015.

[5] Dinulović, M., Rašuo, B., Trninić, M., Adžić, V.: Numerical Modeling of Nomex Honeycomb Core Composite Plates at Meso Scale Level, FME Transactions. Vol. 48, No. 4, pp. 874-881, 2020.

[6] Maksimović, K., Maksimović, M., Vasović Maksimović, I., Rašuo, B., Maksimović, M.: Postbuckling and Failure Analysis of Layered Composite Panels, FME Transactions, Vol. 48, No. 2, pp. 447-453, 2020.

[7] Garinis, D., Dinulovic, M., Rašuo, B.: Dynamic analysis of modified composite helicopter blade, FME Transactions, Vol. 40, No. 2, pp. 63-68, 2012.

[8] Watkins, RJ, Santillan, S, Radice, J, Barton, O.: Vibration response of an elastically pointsupported plate with attached masses, Thin-Walled Structures Vol. 48, pp. 519-527, 2010.

[9] Yu, S.D.: Free and forced flexural vibration analysis of cantilever plates with attached point mass, Journal of Sound and Vibration, Vol. pp. 321-270-285, 2009.

[10] Kumar, B., Ranjan, V.: The Effects of attached Discrete Patches and Point Masses on Eigen Values and Sound Radiation of a Rectangular Plate, Inst Eng India Ser, Vol. 95(4), pp. 359-366, 2014.

[11] Alibeigloo, A, Kari, M.R.: Force vibration analysis of antisymmetric laminated rectangular plates with distributed patch mass using third- order shear deformation, Thin-Walled Struct,Vol.47, pp.653-660, 2009.

[12] Han, Y, W , plang, P, Fan, H, Sun, F. Chen L, Fang, D.: Free vibration of CFRC lattice-core sandwich cylinder with attached mass, Composites Science and Technology, Vol.118, pp. 226-235, 2015.

[13] Khalili, S.M.R, Tafazoli, S, Malekzadeh Fard K.: Free vibrations of laminated composite shells with uniformly distributed attached mass using higher order shell theory including stiffness effect, Journal of Sound and Vibration, Vol. 330, pp. 6355-6371, 2011.

[14] Hosseini-Hashemi, Sh., Rezaee, V., Atashipour, S.R., Girhammar, U.A.: Accurate free vibration analysis of thick laminated circular plates with attached rigid core, Journal of Sound and Vibration, Vol.331, pp. 5581-5596, 2012.

[15] Malekzadeh, K., Sayyidmousavi, A.: Free vibration analysis of sandwich plates with a uniformly distributed attached mass flexible core and different boundary conditions, Journal of Sandwich Structures and Materials, Vol.12, No.6, pp.709-732, 2010.

[16] Rahmane, A., Benmansour, T., Bouakba, M., Ikhlas M.:Factors influencing the effect of attached mass on dynamic behavior of laminate composite plates using Taguchi technique, J Braz. Soc. Mech. $\begin{array}{llll}\text { Sci. } & \text { Eng, } & \text { Vol. } & 40,\end{array}$ https://doi.org/10.1007/s40430-018-0987-x, 2018.

[17] Omidvar, H., Azari, K.. K, Mohammad, Taheri, A, Saghafi, A. A.: Impact and Ballistic Behavior Optimization of Kevlar-Epoxy Composites by Taguchi Method, Arab J Sci Eng, Vol.38, pp.1161-1167, 2013.

[18] Sunny, T., Babu, J., Philip, J.: Experimental Studies on Effect of Process Parameters on Delamination in Drilling GFRP Composites using Taguchi Method, Procedia Materials Science, Vol.6, pp. 1131-1142, 2014.

[19] Singh, M., Saini, J. S., Bhunia, H., Singh, P.: Application of Taguchi method in the optimization of geometric parameters for double pin joint configurations made from glass-epoxy nanoclay laminates, Journal of Composite Materials. https://doi:10.1177/0021998316678920, 2016.

[20] Chen, Sh.-Ch., Chien, R.-D.: Optimization of the injection modling process for shortfiber_reinforced composite, Mechanics of Composite Materials, Vol. 47, No.3, pp. 519-532, 2011.

[21] Rueppel, M., Rion, J., Dransfeld, C., Fischer, C. Masania, K. : Damping of carbon fibre and flax fibre angle-ply composite laminates, Composites Science and Technology, Vol. 146, pp.1-9, 2017.

[22] Wang, Z., Li L., Guild, M. : Measurement of dynamic modulus of elasticity and damping ratio of wood-based composites using the cantilever beam vibration technique, Construc and Buil Mater Vol. 28, pp. 831-834,2012. 
[23] Arikoglu, A., Ozturk, A.G.: A novel approach for in-plane vibration and damping analysis of arbitrarily curved laminated composite and sandwich beams, Composite Structures, Vol. 253, p. 112781, 2020.

[24] He, Y., Xiao, Y., Liu, Y., Zhang, Z. :An efficient finite element method for computing modal damping of laminated composites: theory and experiment, Composite Structures, Vol.184, pp.728-741, 2018.

[25] Pereira, D.A., Guimarães, T.A.M., Resende, H.B., Rade, D.A.: Numerical and experimental analyses of modal frequency and damping in tow-steered CFRP laminates, Composite Structures,Vol. 244, p.112190, 2020.

[26] El Mahi, A., Assrar, Sefrani, Y., Berthelot JM.: Damping analysis of orthotropic composite materials and laminates, Compos Part B-Eng vol. 39, pp.1069-1076, 2008.

[27] Malakhov, A.V. and Polilov, A.N.:Design of composite structures reinforced curvilinear fibres using FEM, Composites Part A: Applied Science and Manufacturing, Vol. 87, pp. 23-28, 2016.

[28] Liljedahl, CDM., Crocombe, AD., Wahad, M.A., Ashcroft, I.A.: Damage modeling of adhesively bonded joints, Int J Fract, Vol. 141, pp.147-161, 2006.

[29] Aydogdu, M., Filiz, S.: Vibration analysis of symmetric laminated composite plates with attached mass, Mechanics of Advanced Materials and Structures, Vol.23 No.02, pp. 136-145, 2015.

[30] Madić, M.J. and Radovanović, M.R.: Optimal selection of ANN training and architectural parameters using Taguchi method: A case study, FME Transactions, Vol. 39, No. 2, pp.79-86, 2011.

\section{NOMENCLATURE}

\begin{tabular}{|c|c|}
\hline$f r$ & resonance frequency \\
\hline$\zeta$ & damping ratio \\
\hline$\{y\}$ & nodal displacement vector \\
\hline$\gamma_{\mathrm{xz}}, \gamma_{\mathrm{yz}}$ & shear strain \\
\hline$u, v, w$ & $\begin{array}{l}\text { displacements of a point in the } \mathrm{x}, \mathrm{y} \\
\text { and } \mathrm{z} \text { directions }\end{array}$ \\
\hline$\{\ddot{y}\}$ & the nodal acceleration vector \\
\hline$\sigma_{\mathrm{xx}}, \sigma_{\mathrm{xy}}, \sigma_{\mathrm{yy}}$ & $\begin{array}{l}\text { stress components in Cartesian co- } \\
\text { ordinates }\end{array}$ \\
\hline$\varepsilon_{\mathrm{xx}}, \varepsilon_{\mathrm{yy}}, \varepsilon_{\mathrm{xy}}$ & strains along the $x$ and $y$ directions \\
\hline$Q^{\prime}{ }_{i j}$ & $\begin{array}{l}\text { components of transformed lamina } \\
\text { stiffness matrix }\end{array}$ \\
\hline & layer thickness \\
\hline$A_{i j}, B_{i j}, D_{i j}$ & $\begin{array}{l}\text { extensional, coupling and bending } \\
\text { stiffness coefficients }\end{array}$ \\
\hline${ }_{12}, G_{13}, G_{23}$ & shear modulus \\
\hline
\end{tabular}

\begin{tabular}{|c|c|}
\hline $\begin{array}{l}v_{12} v_{13} v_{23} \\
N\end{array}$ & $\begin{array}{l}\text { Poisson's ratio } \\
\text { stress resultant }\end{array}$ \\
\hline$\gamma_{x x}, \gamma_{y y}, \gamma_{x y}$ & shear strain \\
\hline & components of bending moment \\
\hline $\mathrm{E}_{\mathrm{c}}$ & kinetic energy of a laminate \\
\hline $\mathrm{U}_{\mathrm{d}}$ & strain energy of a laminate \\
\hline $\mathrm{u}_{0}, \mathrm{v}_{0}, \mathrm{w}_{0}$ & $\begin{array}{l}\text { displacements of a point in the } \\
\text { midplane }\end{array}$ \\
\hline$\rho$ & mass per unit area of the plate \\
\hline$\omega$ & frequency of free vibrations \\
\hline $\mathrm{M}_{\mathrm{i}}$ & mass of the attached particle \\
\hline$N i$ & $\begin{array}{l}\text { number of particles attached to the } \\
\text { composite plate }\end{array}$ \\
\hline$[\mathrm{M}]$ & structural mass matrix \\
\hline [K] & structural stiffness matrix \\
\hline$\Delta \mathrm{f}$ & $\begin{array}{l}\text { frequency bandwidth between the } \\
\text { two half power points }\end{array}$ \\
\hline$\left(x_{p}, y_{p}\right)$ & $\begin{array}{l}\text { position of particles attached to the } \\
\text { composite plate }\end{array}$ \\
\hline S & $\begin{array}{l}\text { standard deviation of measured } \\
\text { values }\end{array}$ \\
\hline $\mathrm{n}$ & $\begin{array}{l}\text { number of observations of the } \\
\text { experiment }\end{array}$ \\
\hline$u$ & signal-noise ratio $(\mathrm{S} / \mathrm{N})$ \\
\hline$y_{i}$ & observed data \\
\hline
\end{tabular}

\section{ОДНОС МОДАЛНОГ ПРИГУШЕЊА КОД СИМЕТРИЧНОГ ЛАМИНАТНОГ КОМПОЗИТА ПОД УТИЦАЈЕМ ПРИЧВРШЋЕНЕ МАСЕ ПРИМЕНОМ ЕКСПЕРИМЕНТАЛНОГ ДИЗАЈНА}

\section{Р. Абделхафид}

Ламинатни материјали имају широку примену у грађевинарству као и у војној и авио индустрији. Потребно је истражити њихова механичка и физичка својства. Рад се бави проблемом утицаја причвршћене масе на однос пригушења угла симетричног слоја ламинатног композита коришћењем Тагучи методе. Разматрају се следећи параметри фактора: локација причвршћене масе од притегнуте ивице, редослед слагања и гранични услови. Резултати показују да је однос пригушења ламинатних плоча осетљив на причвршћену масу, при чему је пропорционалан локацијама причвршћене масе. Утврђено је да причвршћена маса смањује фреквенцију а да повећава однос пригушења, ако је уметнута у тачки изван нодалне линије. Постоји добра корелација између нумеричких резултата добијених за основну фреквенцију применом софтвера ANSYS у поређењу са резултатима добијеним експерименталним путем. 